\title{
PENINGKATAN KOMPETENSI MANAJEMEN ASFIKSIA BAYI BARU LAHIR MELALUI METODE COOPERATIVE LEARNING
}

\author{
Reni M. Kusuma*, Anita D. Anwar**, Dwi Prasetyo*** \\ * STIKES Achmad Yani Yogyakarta \\ ** Bagian Fetomaternal Fakultas Kedokteran Universitas Padjajaran \\ *** Bagian Anak Fakultas Kedokteran Universitas Padjajaran
}

\begin{abstract}
Background: The competence of asphyxia management on newborn baby is essential for midwive- The quality of learning process should be improved by applying interactive learning method. The cooperative learning method is often applied to enhance the effectiveness of clinical learning process. The purpose of this research was to analyse the influence of cooperative learning on competence which consists of student's knowledge, attitude, dan skill in comparison to teacher-centered learning method.

Method: This is a quasi-experimental research with control group pre-test and post-test design Samples were third semester students at Stikes A. Yani Yogyakarta. The samples were 80 students in cooperative learning group and 90 students in teacher-centered learning group.

Results: The result-showed that there was an improvement of knowledge in cooperative learning group compared to teacher-centered learning group $(p=0.002)$. The improvement of student's attitude in cooperative learning group was significantly bigher than teacher-centered learning group $(p=0.001)$. In the field of skills, cooperative learning group achieved higher score rather than teacher-centered learning group, although not significant $(p=0.671)$. The competence was significantly higher in cooperative learning group rather than in teacher-centered learning group $(p=0.027)$. Correlation between competence and method of learning was weak $\left(r_{p b i}=0.134, p=0.041\right)$.

Conclusion: Cooperative learning method is proven to be able to improve students' knowledge, attitude and skills. The difference is not significant for skills domain. Cooperative learning method is proven to improve students' competence in carrying out the management of newborn babies asphyxia, even though the correlation is weak.
\end{abstract}

Keywords: Cooperative learning, Competence, Teacher-centered learning

\section{ABSTRAK}

Latar Belakang: Manajemen asfiksia bayi baru lahir merupakan salah satu kompetensi pokok bada profesi bidan. Perlu ditingkatkan kualitas pembelajarannya dengan menerapkan metode pembelajaran yang lebih interaktif. Metode cooperative learning banyak dipakai untuk meningkatkan efektifitas proses pembelajaran klinik. Penelitian ini bertujuan untuk membandingkan metode cooperative learning dibandingkan metode teacher-centered untuk meningkatkan kompetensi manajemen asfiksia bayi baru lahir pada mahasiswa akademi Kebidanan.

Metode: Penelitian ini menggunakan metode kuasi eksperimental dengan rancangan control group pre-test and post-test. Sampel dalam penelitian ini adalah mahasiswa semester III di Stikes A. Yani Yogyakarta. Sampel berjumlah 80 mahasiswa pada kelompok cooperative learning dan 90 mahasiswa pada kelompok teacher-centered learning.

Hasil: Penelitian menunjukkan terdapat kenaikan skor pengetahuan pada metode cooperative learning dibandingkan metode teacher-centered learning $(\mathrm{p}=0,002)$. Kenaikan sikap lebih tinggi pada metode cooperative learning dibanding pada metode teacher-centered learning $(\mathrm{p}=0,001)$. Untuk ranah keterampilan metode cooperative learning meningkatkan skor sedikit di atas teacher-centered learning dan tidak bermakna $(p=0,671)$. Kompetensi berhasil meningkat secara bermakna pada cooperative learning dibandingkan teacher-centered learning $(p=0,027)$. Korelasi antara kompetensi dan metode pembelajaran lemah $\left(r_{p b i}=0,134 ; p=0,041\right)$.

Korespondensi: join.reni@gmail.com 
Kesimpulan: Metode cooperative learning terbukti dapat meningkatkan pengetahuan dan sikap mahasiswa. Ranah keterampilan dalam penelitian ini memperlihatkan tidak ada perbedaan antara kedua kelompok. Metode cooperative learning terbukti meningkatkan kompetensi mahasiswa dalam melakukan manajemen asfiksia bayi baru lahir, meskipun korelasinya lemah.

Kata kunci : Cooperative Learning, Kompetensi, Teacher-centered learning

\section{PENDAHULUAN}

Institusi pendidikan kebidanan, salah satunya Sekolah Tinggi Ilmu Kesehatan Jenderal Achmad Yani Yogyakarta, berkewajiban ikut serta dalam program penurunan angka kematian bayi (AKB), mahasiswa kebidanan harus kompeten dalam melakukan manajemen asfiksia bayi baru lahir karena asfiksia merupakan penyebab tertinggi AKB. Lulusan kebidanan yang kurang kompeten dapat memengaruhi kinerjanya selama bertugas sebagai bidan pelaksana, padahal bidan ditempatkan pada lini terdepan penurunan AKB. Partisipasi institusi pendidikan kebidanan dapat dimulai dari pelaksanaan proses pembelajaran yang berkualitas. Peningkatan kualitas dilakukan dengan cara menerapkan metode pembelajaran yang lebih banyak melibatkan mahasiswa sehingga mahasiswa menjadi lebih aktif.

Manajemen asfiksia bayi baru lahir merupakan satu dari lima kompetensi yang harus dikuasi oleh mahasiswa Diploma III Kebidanan. Empat kompetensi lain yang dimaksudkan, yaitu pemeriksaan fisiks bayi baru lahir, pemberian imunisasi, penatalaksaan pijat bayi, dan penatalaksanaan manajemen terpadu bBayi sSakit (MTBS). Kompetensi tersebut terdapat dalam mata kuliah Asuhan Neonatus, Bayi, dan Balita.

Manajemen asfiksia ini dipilih oleh institusi sebagai kompetensi yang wajib dikuasai oleh mahasiswa Diploma III Kebidanan dalam rangka ikut serta menurunkan kejadian kematian bayi di Indonesia.

Proses pembelajaran mata kuliah Asuhan Neonatus, Bayi, dan Balita menjadi pilihan dalam penelitian ini karena di dalamnya terdapat kompetensi manajemen asfiksia bayi baru lahir dan kompetensi ini terkait dengan kebutuhan masyarakat agar tingkat angka kejadian kematian bayi dapat diturunkan. Fakta lain menunjukkan bahwa hasil belajar tahun 2011 di Stikes A. Yani Yogyakarta pada mata kuliah ini kurang memuaskan.
Hal itu ditandai dengan hasil belajar berkriteria sangat memuaskan hanya $8 \%$. Sebanyak 22\% mahasiswa mengulang pada ujian praktikum penatalaksanaan resusitasi bayi baru lahir. Data ini menunjukkan bahwa capaian kompetensi mahasiswa belum memuaskan sehingga diperlukan pendekatan pembelajaran yang lebih inovatif sehingga mampu mendukung tercapainya kompetensi.

Metode pembelajaran yang mengandung method of inquiry tercermin dalam SCL. ${ }^{1,2}$ Penelitian ini mengambil cooperative learning sebagai salah satu variabelnya untuk diterapkan dalam proses pembelajaran mahasiswa Diploma III Kebidanan.

Metode cooperative learning telah digunakan oleh beberapa sekolah, tetapi belum ada yang menerapkannya dalam proses pembelajaran bidang kesehatan, seperti kedokteran, kebidanan, atau keperawatan.

Penelitian ini memiliki tujuan untuk membandingkan capaian kompetensi (pengetahuan, sikap, dan keterampilan) manajemen asfiksia bayi baru lahir antara metode teacher-centered learning dan cooperative learning. ${ }^{3-7}$

\section{METODE}

Rancangan penelitian ini adalah control group pre-test and post-test dengan pengamatan sebelum dan sesudah intervensi. ${ }^{8}$ Skor pre-test dan post-test dilakukan untuk mengukur pengetahuan, sikap, dan keterampilan tentang manajemen asfiksia bayi baru lahir pada mahasiswa. Intervensi yang dilakukan adalah metode cooperative learning sedangkan kelompok kontrol tetap memakai teacher-centered learning (menggunakan kuliah dan demonstrasi). Selama proses pelaksanaan cooperativelearning mahasiswa dalam satu kelas dibagi dalam kelompok-kelompok kecil beranggotakan 5 orang yang selanjutnya disebut sebagai kelompok awal. Setiap anggota kelompok mendapatkan tugas yang berbeda- 
beda, yaitu kehidupan janin intrauterin, masa transisi perubahan pernapasan janin menjadi neonatus, asuhan bayi baru lahir normal, kewenangan bidan, dan bayi asfiksia yang mendapat tindakan resusitasi.

Setiap mahasiswa memiliki tugas masing-masing di dalam kelompok awal. Mahasiswa yang memiliki tugas yang sama berkumpul dalam kelompok ahli dan mereka bekerjasama mencari referensi yang sesuai dengan tugas. Referensi yang didapatkan kemudian dikaji bersama sampai setiap mahasiswa memahami maksud tugas yang diberikan. Mahasiswa yang sudah memperoleh dan menguasai materi sesuai tugas, kemudian kembali ke dalam kelompok awal untuk membagikan hasil kajian dari kelompok ahli., 9-11

Penelitian ini dilakukan di Stikes A. Yani Yogyakarta yang dilakukan selama bulan Oktober sampai November 2013. Mahasiswa yang dilibatkan sebagai subjek penelitian adalah mahasiswa Diploma III Kebidanan Stikes A. Yani Yogyakarta yang memenuhi kriteria inklusi (mahasiswa semester III reguler Stikes A. Yani Yogyakarta yang telah lulus pada mata kuliah Askeb I pada semester II dan yang memenuhi kehadiran lebih dari $75 \%$ ) serta bersedia mengikuti penelitian dengan mengisi lembar persetujuan (informed consent). Adapun kriteria eksklusi dari penelitian ini adalah mahasiswa yang tidak hadir pada saat penelitian dan tidak bersedia mengikuti penelitian. Sebanyak 220 mahasiswa yang terdapat di 4 kelas memenuhi kriteria inklusi. Keempat kelas tersebut dipilih secara acak sederhana dengan uang logam, 2 kelas untuk kelompok intervensi dan 2 kelas kelompok kontrol.

Instrumen yang digunakan dalam penelitian ini ditujukan untuk mengukur aspek pengetahuan, sikap, dan keterampilan masing-masing sampel. Instrumen penelitian yang dipakai untuk mengukur ranah pengetahuan berbentuk soal pilihan ganda. Instrumen penelitian untuk mengukur ranah sikap berupa kuesioner. Instrumen penelitian untuk mengukur ranah keterampilan berupa checklist. Instrumen penelitian ini diambil dari Buku Pedoman Pelatih Manajemen Asfiksia Bayi Baru Lahir bagi Bidan tahun 2011.

Ethical Clearance diperoleh dari Komite Etik Penelitian Kesehatan dan surat permohonan izin penelitian dari Ketua Program Studi Magister Kebidanan Fakultas Kedokteran Universitas Padjadjaran Bandung dan ijin penelitian dari Ketua Program Studi Diploma III Kebidanan.

\section{HASIL DAN PEMBAHASAN}

Dari jumlah subjek penelitian 220 mahasiswa, 50 mahasiswa dieksklusi karena subjek penelitian tidak hadir pada serangkaian pengambilan data. Subjek penelitian yang dianalisis berjumlah 170 mahasiswa, yaitu 80 mahasiswa dalam kelompok intervensi (cooperative learning) dan 90 mahasiswa dalam kelompok kontrol (teacher centered learning). Karakteristik mahasiswa yang terlibat pada dua kelompok tersebut ditampilkan pada tabel 1 .

Tabel 1. Karakteristik indeks prestasi dan nilai pada dua kelompok

\begin{tabular}{lcccc} 
Karakteristik Responden & $\begin{array}{c}\text { Co operative } \\
\text { Learning } \\
(\mathbf{n}=\mathbf{8 0})\end{array}$ & $\begin{array}{c}\text { Teacher Centered } \\
\text { Learning (n=90) }\end{array}$ & Nilai p \\
\hline IPK & $0(0 \%)$ & $7(8 \%)$ & 0,007 \\
& $\begin{array}{c}\text { Cumlaude } \\
\text { Sangat } \\
\text { memuaskan }\end{array}$ & $48(60 \%)$ & $61(68 \%)$ & \\
& Memuaskan & $32(40 \%)$ & $22(24 \%)$ & \\
\hline \multirow{2}{*}{ Askcb I } & Nilai A & $9(11 \%)$ & $14(16 \%)$ & 0,213 \\
& Nilai B & $65(81 \%)$ & $74(82 \%)$ & \\
& Nilai C & $6(8 \%)$ & $2(2 \%)$ & \\
\hline
\end{tabular}


Kesebandingan antara dua kelompok dapat dilihat dari IPK sebelumnya dan nilai Askeb I. Perolehan IPK ratarata kedua kelompok tidak seimbang. Kelompok kontrol memiliki perolehan IPK lebih tinggi jika dibandingkan dengan kelompok cooperative learning. Nilai mahasiswa tidak jauh berbeda antara kelompok cooperative learning dan teachercentered learning.

Tabel 2 menunjukkan perbandingan capaian ranah pengetahuan pada kedua kelompok.

Tabel 2. Perbandingan skor pengetahuan antara kelompok cooperative learning dan teacher-centered learning

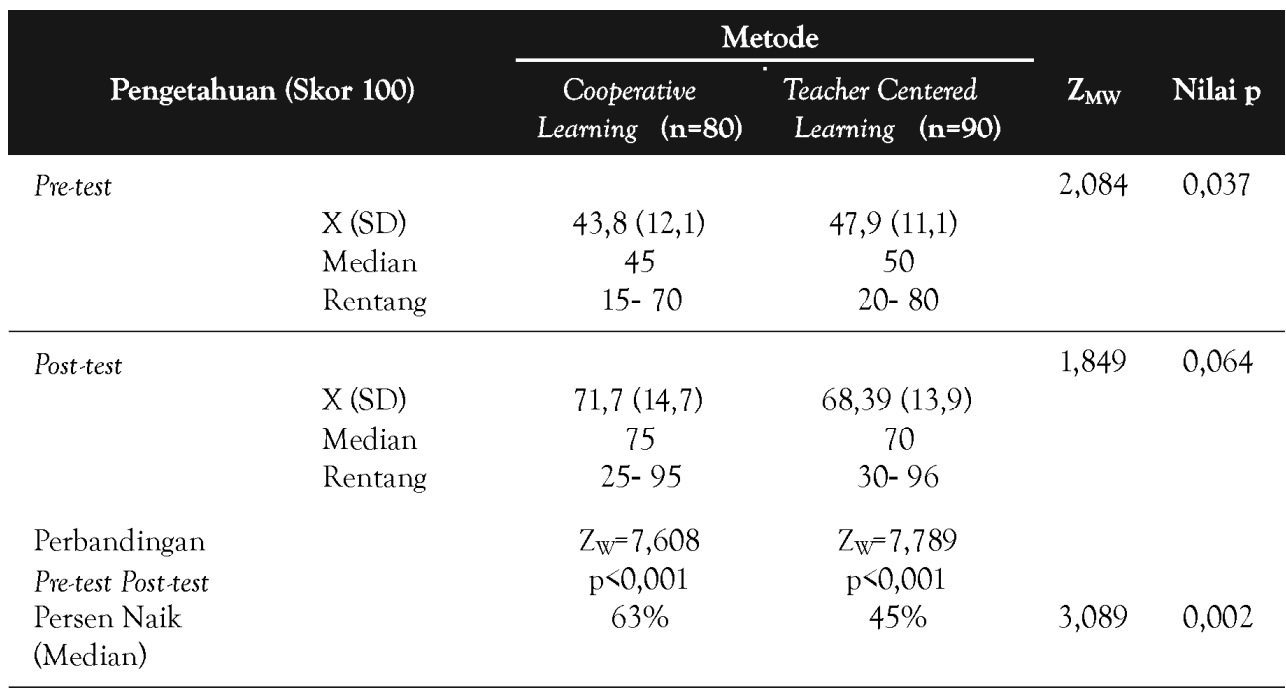

Keterangan: $\mathrm{Z}_{\mathrm{MW}}=$ Uji Mann-Whitney; $\mathrm{Z}_{\mathrm{W}}=$ Uji Wilcoxon

Skor pretest antara kedua metode menunjukkan beda bermakna dengan skor lebih tinggi pada mahasiswa kelompok teacher-centered learning. Pada post-testskor kedua kelompok tidak berbeda bermakna. Uji Mann-Whitney pada median persentase kenaikan pengetahuan menunjukkan perbedaan bermakna $(\mathrm{p}<0,001)$ dimana kenaikan skor pengetahuan kelompok cooperative learning lebih tinggi dibanding teacher-centered learning.

Tabel 3 menyajikan hasil analisis ranah sikap antara kedua kelompok mahasiswa.

Tabel 3. Perbandingan skor sikap antara kelompok cooperative learning dan teacher-centered learning

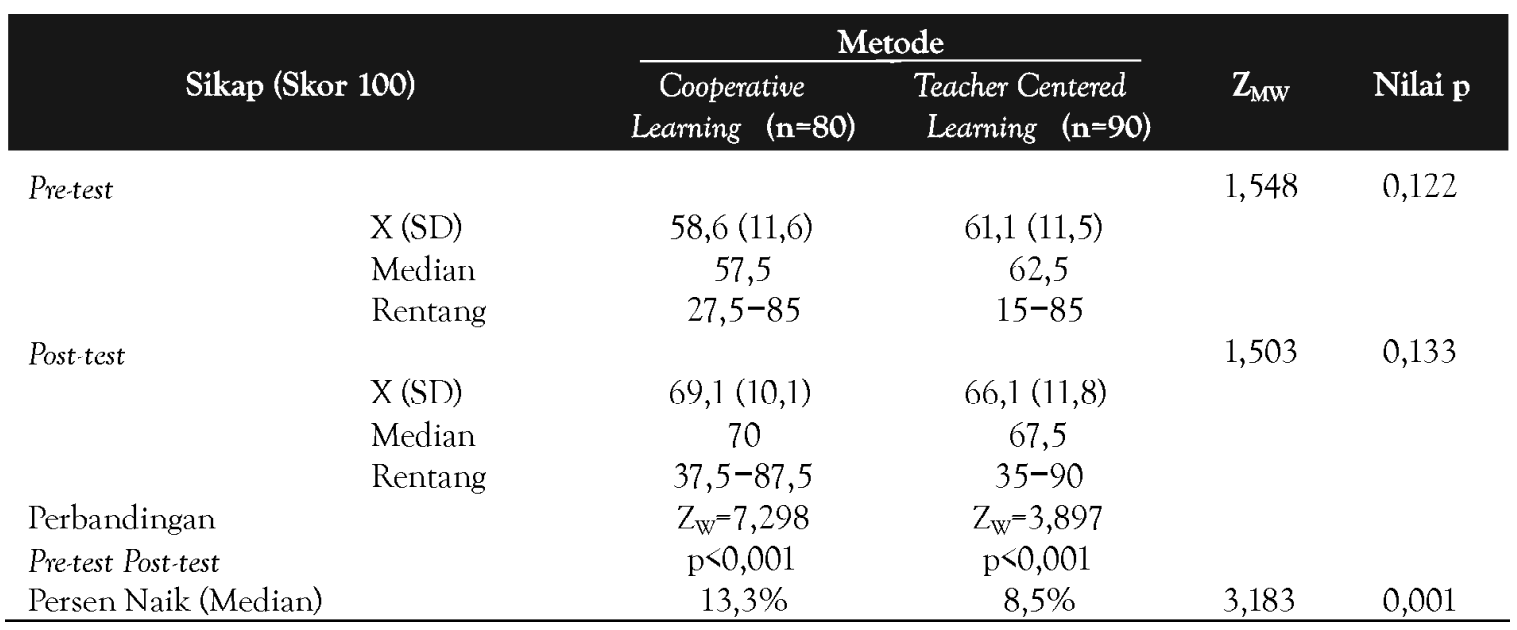

Keterangan: $\mathrm{Z}_{\mathrm{MW}}=$ Uji Mann-Whitney; $\mathrm{Z}_{\mathrm{W}}=\mathrm{Uji}_{\mathrm{ji}} \mathrm{W}$ ilcoxon 
Skor sikap pre-test dan post-test pada kedua kelompok tidak berbeda bermakna. Uji Mann-Whitney dari median persentase kenaikan skor sikap menunjukkan perbedaan bermakna $(\mathrm{p}=0,001)$ yaitu sikap kelompok cooperative learning lebih baik dibandingkan kelompok teachercentered learning. Hasil analisis ranah keterampilan disajikan dalam tabel 4 berikut ini.

Tabel 4. Skor keterampilan antara kelompok cooperative learning dan teachercentered learning

\begin{tabular}{lcc}
\multirow{2}{*}{ Keterampilan } & \multicolumn{2}{c}{ Metode } \\
\cline { 2 - 3 } & $\begin{array}{c}\text { Cooperative Leaming } \\
(\mathbf{n}=\mathbf{8 0})\end{array}$ & $\begin{array}{c}\text { Teacher Centered } \\
\text { Learning }(\mathbf{n}=\mathbf{9 0})\end{array}$ \\
X (SD) & $83,3(6,8)$ & $83,1(6,1)$ \\
Median & 84,1 & 83,1 \\
Rentang & $56-95,5$ & $59-94$ \\
& & $\mathrm{Z}_{\mathrm{MW}}=0,425$ \\
& & $\mathrm{p}=0,671$ \\
\hline
\end{tabular}

Skor keterampilan pada kelompok mahasiswa dengan cooperative learning sedikit lebih tinggi dibandingkan mahasiswa dengan teachercentered learning meskipun tidak bermakna $(\mathrm{p}=0,671)$.
Secara keseluruhan, pencapaian kompetensi antara kelompok cooperative learning dan teachercentered learning ditampilkan pada tabel 5 .

Tabel 5. Perolehan skor kompetensi antara kelompok cooperative learning dan teacher-centered learning

\begin{tabular}{lcc} 
& \multicolumn{2}{c}{ Metode } \\
\cline { 2 - 3 } Kompetensi & $\begin{array}{c}\text { Cooperative Learning } \\
(\mathbf{n}=\mathbf{8 0})\end{array}$ & $\begin{array}{c}\text { Teacher Centered } \\
\text { Learning }(\mathbf{n}=\mathbf{9 0})\end{array}$ \\
X (SD) & $74,7(8,1)$ & $72,5(7,8)$ \\
Median & 75,3 & 72,7 \\
Rentang & $49,2-88,5$ & $50,8-88,8$ \\
& & $\mathrm{Z}_{\mathrm{MW}}=1,929 ;$ nilai $\mathrm{p}=$ \\
& 0,027 \\
\hline
\end{tabular}

Kompetensi mahasiswa kelompok cooperative learning secara bermakna lebih tinggi dibandingkan kompetensi mahasiswa kelompok teachercentered learning $(\mathrm{p}=0,027)$.

Data ranah pengetahuan mahasiswa dalam melakukan manajemen asfiksia bayi baru lahir diperoleh sebelum dan setelah subjek penelitian mendapatkan perlakuan. Uji Mann-Whitney yang dihitung dari median persentase kenaikan pengetahuan menghasilkan nilai $\mathrm{p}=0,002$ (Tabel 4.2), sehingga simpulannya adalah terdapat perbedaan bermakna antara pengetahuan kelompok cooperative leming dan teachercentered learning.
Karakteristik subjek penelitian memperlihatkan ketidakseimbangan perolehan IPK antara kelompok cooperative learning dan teachercentered learning. Pada awal penelitian indeks prestasi kumulatif (IPK) rata-rata digunakan sebagai variabel untuk menguji homogenitas sampel. Diperoleh IPK kelompok teachercentered learning lebih tinggi jika dibandingkan dengan kelompok cooperative leaming. Hal ini berarti bahwa hasil penelitian ini harus diinterpretasikan dengan mempertimbangkan beda IPK sebelumnya. 


\section{Peningkatan ranah pengetahuan}

Tabel 2 menunjukkan bahwa ranah pengetahuan mahasiswa yang mendapat metode cooperative learning hasilnya lebih baik daripada mahasiswa yang diberi metode teachercentered learming. Fakta di atas menunjukkan bahwa metode cooperative learning dapat meningkatkan kemampuan mahasiswa dalam menyerap pengetahuan dengan lebih baik. Selama proses pembelajaran pun mahasiswa saling membantu dan bekerjasama dalam menyusun tugas setiap anggota kelompok, karena satu anggota hanya menyelesaikan/menguasai salah satu bagian materi pelajaran. Setiap anggota kelompok harus berkumpul guna saling membagi pengetahuan tentang janin intrauterin sampai patofisiologi asfiksia lengkap dengan cara penanganannya.

Pengetahuan yang didapatkan oleh mahasiswa selama proses pembelajaran setidaknya baru pada tahap mengerti karena mahasiswa mengelompokkan materi, meringkas bahan bacaan, menyimpulkan, dan menjelaskan kepada mahasiswa lainnya. ${ }^{12}$ Tahap selanjutnya mahasiswa masuk pada tahap pengaplikasian. Aplikasi tindakan manajemen asfiksia bayi baru lahir di dalam laboratorium kebidanan.

Keikutsertaan mahasiswa secara aktif dalam proses pembelajaran dapat mengasah dan menumbuhkan kemampuan berpikir kritis dalam mengkaji pengetahuan yang diperoleh mahasiswa. ${ }^{6}$ Pengetahuan yang telah dicari, didapatkan, dan dikaji oleh mahasiswa memiliki retensi ingatan yang lebih kuat daripada mahasiswa hanya pasif selama proses pembelajaran. Pembelajaran kooperatif dapat membantu siswa untuk mencapai dan mengembangkan pengetahuan sebagai salah satu bagian dari kompetensi serta mampu menyimpan materi pelajaran lebih banyak daripada mahasiswa yang pasif. $5,13,14$

\section{Peningkatan ranah sikap}

Data ranah sikap mahasiswa tentang pelaksanaan manajemen asfiksia bayi baru lahir diambil sebelum dan setelah subjek penelitian mendapatkan perlakuan berupa metode cooperative learning dan teachercentered learning. Sikap mahasiswa yang menerima metode cooperative learning lebih baik daripada mahasiswa yang mendapat metode teacher-centered learning. Temuan ini membuktikan teori yang menjelaskan bahwa penerapan metode cooperative learning dalam proses pembelajaran selain mendidik aspek kognitif mahasiswa, juga memupuk kecerdasan sosial yang dinyatakan dalam suatu sikap. Salah satu filosofi dalam metode cooperative learning adalah pembelajaran dikatakan belum tuntas, jika satu dari anggota kelompok masih ada yang belum memahami pokok materi yang ditugaskan. ${ }^{9,10}$

Penerapan metode cooperative learning mengkondisikan setiap anggota kelompok memiliki ketergantungan positif. Ketergantungan tersebut menimbulkan tindakan kerjasama dan saling tolong menolong antar-anggota kelompok, baik di dalam kelompok awal (kelompok yang terdiri atas 5 orang dengan tugas berbeda-beda) maupun kelompok ahli (kumpulan anggota yang memiliki tugas sejenis). Tindakan yang dilatihkan dalam proses pembelajaran ini, jika dikerjakan secara berkelanjutan dapat membentuk sikap dan karakter manusiawi bagi mahasiswa. Metode cooperative learning tidak hanya berfokus pada penguasaan materi pelajaran yang seharusnya dikuasai oleh mahasiswa, tetapi juga pengembangan sikap, kepribadian, dan karakter mahasiswa yang di dalamnya terdapat motivasi untuk lebih kreatif dalam meningkatkan kemampuannya. ${ }^{4,5,10}$

Sikap mahasiswa yang terbentuk dalam proses pembelajaran menggunakan metode cooperative learning ini masuk dalam tahap penilaian/penentuan sikap. Tahap penilaian ini mencakup kemampuan mahasiswa dalam membawa diri sesuai dengan hasil penilaian yang diperolehnya. Pencapaian tahap ini terlihat pada saat setiap anggota diberi tugas dan dikerjakan secara bersamasama. Mahasiswa mau menerima untuk mengerjakan tugas secara bersama dan berbagi dengan mahasiswa lain. ${ }^{15}$ Kecerdasan sosial tersebut juga berdampak pada sikap mahasiswa dalam manajemen asfiksia bayi baru lahir. Sikap mahasiswa diukur melalui pertanyaan dalam kuesioner. Hasilnya mahasiswa yang menerapkan metode cooperative learning memiliki sikap yang lebih baik daripada mahasiswa yang mengikuti metode teachercentered learning.

\section{Perubahan ranah keterampilan}

Pengambilan data keterampilan mahasiswa dalam melakukan manajemen asfiksia bayi baru lahir hanya satu kali, yaitu setelah diterapkannya metode cooperative learning dan teacher-centered learning pada masing-masing kelompok. Tabel 4 menyimpulkan bahwa tidak terdapat 
perbedaan bermakna antara keterampilan mahasiswa yang menjalani metode cooperative learning dan teachercentered learning. Temuan ini, serupa dengan hasil penelitian Qudsyi dkk. yang menyatakan bahwa tidak terdapatnya perbedaan prestasi belajar yang di dalamnya terkandung ranah keterampilan, antara kelompok siswa yang diberikan pembelajaran kooperatif (cooperative learning) dan pembelajaran tradisional (teachercentered learning). ${ }^{16}$ Salah satu penyebab tidak terdapatnya perbedaan tersebut adalah jumlah pertemuan yang hanya dilakukan satu kali. Penelitian ini dilakukan bersamaan dengan berlangsungnya proses pembelajaran, sehingga jumlah pertemuan dengan mahasiswa diatur oleh institusi. Pelaksanaan metode cooperative learning hanya dilakukan satu kali tatap muka dan mungkin pertemuan tersebut merupakan masa penyesuaian mahasiswa terhadap metode pembelajaran baru. Pembelajaran yang biasanya dilakukan yaitu teachercentered learning tidak terlalu menuntut keaktifan mahasiswa, tetapi dalam metode cooperative learning ini mewajibkan mahasiswa aktif dalam mencari, menemukan, mengkaji, dan berbagi kepada mahasiswa lain.

Penerapan metode cooperative learning yang hanya dilakukan satu kali pertemuan, besar kemungkinan mahasiswa belum menginternalisasi proses pembelajaran tersebut. Pertemuan pertama dapat dikatakan sebagai fase perkenalan karena periode sebelumnya belum pernah melaksanakan metode cooperative learning. Jika mahasiswa sudah mengenal dan mengalami, maka fase internalisasi tujuan karakteristik metode cooperative learning, besar kemungkinan ranah keterampilan dapat ditingkatkan dan terdapat perbedaan dengan keterampilan yang diperoleh dari penerapan metode teachercentered learning.

Mahasiswa yang menerapkan metode cooperative learning seharusnya memiliki kemampuan keterampilan yang lebih baik, karena dalam ranah pengetahuan dan sikap terbukti terdapat perbedaan secara signifikan. ${ }^{5}, 17$ Hasil penelitian tersebut membuktikan bahwa penerapan metode-cooperative learning dapat meningkatkan keterampilan mahasiswa yang dilaksanakan dalam kerjasama kelompok.

Penelitian ini juga tidak menunjukkan perbedaan kompetensi antara kelompok cooperative learning dan teachercentered learning. Metode cooperative learning lebih baik dalam meningkatkan kompetensi mahasiswa khususnya manajemena asfiksia bayi baru lahir. Kompetensi merupakan suatu kesatuan pengetahuan, sikap, dan keterampilan namun dalam penelitian ini ranah keterampilan tidak membuktikan perbedaan metode cooperative learning dengan teachercentered leaming.

Hasil temuan ini menyatakan bahwa metode cooperative learning dapat dijadikan salah satu metode pembelajaran yang dapat diterapkan dalam bidang kesehatan. Lemahnya korelasi metode cooperative learning dalam peningkatan kompetensi manajemen asfiksia bayi baru lahir juga dapat disebabkan oleh singkatnya pelaksanaan metode cooperative learning dalam proses pembelajaran Asuhan Neonatus, Bayi, dan Balita. Pertemuan cooperative learning ini hanya dilakukan 1 kali, sehingga besar kemungkinan pada pertemuan tersebut mahasiswa sedang melalui proses pengenalan metode pembelajaran baru. Dampak pelaksanaan metode cooperative learning dalam penelitian ini hasilnya kurang optimal memengaruhi keterampilan mahasiswa.

Hasil penelitian Setiyani berbeda dengan hasil penelitian ini. Hasil penelitiannya membuktikan peningkatan pemahaman dan keterampilan pada saat mahasiswa melaksanakan pembelajaran dengan metode cooperative learning. ${ }^{5}$ Salah satu sebabnya pada penelitian Setiyani dilakukan selama 3 siklus pembelajaran/ pertemuan, sedangkan penelitian ini pertemuannya hanya sekali. Lemahnya korelasi antara kompetensi dengan metode cooperative learning lebih disebabkan karena kurangnya intensitas atau jumlah pertemuannya.

Keterbatasan penelitian ini yaitu pengambilan data secara pre-test dan post-test dilakukan pada ranah pengetahuan dan sikap, sedangkan ranah keterampilan diambil datanya hanya melalui post-test. Hal ini dilakukan karena keterbatasan waktu (hanya diberikan 1 kali pertemuan untuk penyampaian teori) dan dana. Selain itu instrumen penelitian diambil dari buku Panduan Pelatihan Manajemen Asfiksia Bayi Baru Lahir bagi Bidan dari Kementerian Kesehatan yang berlaku secara nasional dan mungkin kurang tepat diterapkan secara lokal dalam institusi pendidikan kebidanan. 


\section{KESIMPULAN}

Penelitian ini menunjukkan bahwa metode cooperative learning dapat meningkatkan pencapaian ranah pengetahuan, sikap, keterampilan dan kompetensi mahasiswa dibandingkan metode teacher-centered learning. Terdapat korelasi sangat lemah dengan arah positif antara capaian kompetensi (pengetahuan, sikap, dan keterampilan) mahasiswa dengan metode pembelajarannya.

\section{SARAN}

Penelitian lanjut diperlukan dengan melakukan pre-test dan post-test semua ranah. Variabel lain seperti motivasi, kecerdasan emosional, kemampuan pengajar mengelola proses pembelajaran, dan sistem serta fasilitas pendidikan di institusi yang dapat memengaruhi pencapaian kompetensi mahasiswa perlu dipertimbangkan. Pelaksanaan metode cooperative learning perlu dilakukan dengan intensitas yang cukup sehingga dapat melihat efek positif ataupun negatif secara lebih jelas.

\section{DAFTAR PUSTAKA}

1. Kementerian Kesehatan Republik Indonesia. Kurikulum inti pendidikan diploma III kebidanan. Jakarta: Kementerian Kesehatan Republik Indonesia; 2011.

2. Direktorat Akademik Direktorat Jenderal Pendidikan Tinggi. Buku Panduan Pengembangan Kurikulum Berbasis Kompetensi Pendidikan Tinggi (Sebuah alternatif penyusunan kurikulum). Jakarta: Direktorat Akademik Direktorat Jenderal Pendidikan Tinggi; 2008.

3. Parnata IK, Suandi IK. Implementasi cooperative learning dalam pembelajaran sistem akuntansi untuk meningkatkan hasil belajar mahasiswa ditinjau dari prior knowledge mahasiswa. Ragam Jurnal Pengembangan Humaniora. 2010;10(2):98-105.

4. Tisnawati D. Penerapan model cooperative learning tipe STAD dalam pembelajaran biologi untuk meningkatkan prestasi belajar siswa kelas X MAN Model Palu. Derap Pendidikan LPMP Sulawesi Tengah. 2008;2(3):92-107.

5. Setiyani R. Penerapan cooperative learning tipe jigsaw untuk meningkatkan pemahaman dan keterampilan mahasiswa. Jurnal Pendidikan Ekonomi. 2009; 4(1): 69-87.

6. Redhana IW. Meningkatkan keterampilan berpikir kritis siswa melalui pembelajaran kooperatif dengan strategi pemecahan masalah. Jurnal Pendidikan dan Pengajaran IKIP Negeri Singaraja. 2003;3(TH XXXVI):1-13.

7. Armstrong N, Chang S-M, Brickman M. Cooperative learning in industrial-sized biology classes. CBE-Life Science Education. 2007;6:163-71.

8. Arikunto S. Prosedur penelitian suatu pendekatan praktik Jakarta. Jakarta: Rineka Cipta; 2006.

9. Isjoni. Pembelajaran kooperatif meningkatkan kecerdasan komunikasi antar peserta didik. Yogyakarta: Pustaka Pelajar; 2011.

10. Slavin RE. Cooperative learning teori, riset, dan praktik. Bandung: Penerbit Nusa Media; 2005.

11. Suprijono A. Cooperative learning teori $\&$ aplikasi PAIKEM. Yogyakarta: Pustaka Pelajar; 2012.

12. Mayer RE. Rote versus meaningful learning. Theory Into Practice. 2002;41(4):226-32.

13. Partadjaja T, Sulastri M. Penerapan model pembelajaran kooperatif Jigsaw untuk meningkatkan aktivitas dan penalaran mahasiswa pada mata kuliah ilmu budaya dasar. Jurnal Penelitian dan Pengembangan Pendidikan. 2007;1(1):65-77.

14. Prastowo WAE. Model pembelajaran kooperatif tipe think pair share untuk meningkatkan hasil belajar ekonomi materi laporan keuangan perusahaan dagang kelas XII IPS-1 SMA Negeri 3 Semarang Tahun 2009"2010. Jurnal Didaktika. 2009;1(4):797810.

15. Winkel WS. Psikologi pengajaran. Yogyakarta: Media Abadi; 2009.

16. Qudsyi H, Indriaty L, Herawaty Y, Saifullah, Khaliq I, Setiawan J. Pengaruh metode pembelajaran kooperatif (cooperative learning) dan motivasi belajar terhadap prestasi belajar siswa SMA. Proyeksi. 2011;6(2):34-49.

17. Tanner K, Chatman LS, Allen D. Approaches to cell biology teaching: cooperative learning in the science classroom-beyond students working in groups. The American Society for Cell Biology. 2003;2(1):1-5.

18. Setiyani R. Penerapan cooperative learning tipe jigsaw untuk meningkatkan pemahaman dan keterampilan mahasiswa Jurnal Pendidkan Ekonomi. 2009;4(1):69. 87. 